\title{
Serum hepatitis B virus DNA before liver transplantation correlates with HBV reinfection rate even under successful low-dose hepatitis B immunoglobulin prophylaxis
}

\author{
Tetsuya Yasunaka · Akinobu Takaki · Takahito Yagi · Yoshiaki Iwasaki · Hiroshi Sadamori • \\ Kazuko Koike - Satoshi Hirohata • Masashi Tatsukawa - Daisuke Kawai - Hidenori Shiraha • \\ Yasuhiro Miyake $\cdot$ Fusao Ikeda $\cdot$ Haruhiko Kobashi $\cdot$ Hiroaki Matsuda $\cdot$ Susumu Shinoura $\cdot$ \\ Ryuichi Yoshida $\cdot$ Daisuke Satoh $\cdot$ Masashi Utsumi $\cdot$ Teppei Onishi $\cdot$ Kazuhide Yamamoto
}

Received: 20 August 2010/Accepted: 28 February 2011/Published online: 25 March 2011

(C) The Author(s) 2011. This article is published with open access at Springerlink.com

\begin{abstract}
Purpose The combination of hepatitis B immunoglobulin (HBIg) and nucleos(t)ide analogues has been accepted as the best treatment to control hepatitis B recurrence after orthotopic liver transplantation (OLT). However, the optimal dose of HBIg remains unclear. We have previously reported that high-dose HBIg in the early period followed by low-dose HBIg with nucleos(t)ide analogues offers reliable and cost-effective control of hepatitis B recurrence. The aim of this study was to investigate intrahepatic hepatitis B virus (HBV) reinfection status with our clinically successful protocol.

Methods We quantified levels of intrahepatic HBV covalently closed circular (ccc) deoxyribonucleic acid (DNA) and serum hepatitis B core-related antigen ( $\mathrm{HBcrAg}$ ), a new serological marker that can estimate intrahepatic cccDNA
\end{abstract}

T. Yasunaka · A. Takaki ( $($ ) $)$ K. Koike $\cdot$ M. Tatsukawa ·

D. Kawai · H. Shiraha · Y. Miyake · F. Ikeda · H. Kobashi .

K. Yamamoto

Department of Gastroenterology and Hepatology,

Okayama University Graduate School of Medicine,

Dentistry and Pharmaceutical Sciences, Okayama, Japan

e-mail: akitaka@md.okayama-u.ac.jp

T. Yagi $\cdot$ H. Sadamori $\cdot$ H. Matsuda $\cdot$ S. Shinoura $\cdot$

R. Yoshida · D. Satoh · M. Utsumi · T. Onishi

Department of Gastroenterological Surgery,

Okayama University Graduate School of Medicine,

Dentistry and Pharmaceutical Sciences, Okayama, Japan

S. Hirohata

Department of Molecular Biology and Biochemistry,

Okayama University Graduate School of Medicine,

Dentistry and Pharmaceutical Sciences, Okayama, Japan

Y. Iwasaki

Health Service Center, Okayama University, Okayama, Japan levels. Nucleos(t)ide analogues were administered in all cases.

Results No patients showed recurrence of hepatitis B surface antigen (HBsAg) or HBV-DNA. However, HBV, cccDNA, and $\mathrm{HBcrAg}$ were positive in $57 \%$ and $48 \%$ of patients after OLT, respectively. Pre-OLT serum HBVDNA and HBcrAg levels correlated linearly with post-OLT cccDNA levels $(r=0.534, P<0.05$, and $r=0.634$, $P<0.05$, respectively). High serum HBV-DNA and HBcrAg levels, particularly with $>3 \log _{10}$ copies $/ \mathrm{mL}$ and $>4 \log _{10} \mathrm{IU} / \mathrm{mL}$, respectively, at the time of OLT, were associated with high levels of post-OLT cccDNA. Even with our successful protocol, nearly half of patients showed HBV reinfection.

Conclusions Patients with high serum HBV-DNA and HBcrAg levels before OLT (particularly $>3 \log _{10}$ copies/ $\mathrm{mL}$ and $>4 \log _{10} \mathrm{IU} / \mathrm{mL}$, respectively) should be followed with care for $\mathrm{HBV}$ recurrence.

Keywords Hepatitis B virus - Liver transplantation . Recurrence $\cdot \mathrm{HBcrAg} \cdot \mathrm{HBV}$ cccDNA

\section{Introduction}

Prior to the advent of effective post-transplantation antiviral prophylaxis, liver transplantation for hepatitis B virus (HBV)-related disease was usually followed by immediate HBV reinfection of the allograft, resulting in clinical hepatitis $B$ recurrence confirmed by positive results for serum hepatitis B surface antigen (HBsAg) and/or HBV-DNA (deoxyribonucleic acid) [1-3]. Recent studies have found that the combination of hepatitis B immunoglobulin (HBIg) and nucleos(t)ide analogues decreases the risk of $\mathrm{HBV}$ recurrence and achieves a higher rate of graft survival [4-8]. 
However, the optimal dose of HBIg and the target titer for hepatitis B surface antibody (HBsAb) remain unclear. A proposal for guidelines by Roche and Samuel [9] showed that patients with HBV-DNA-positive status before orthotopic liver transplantation (OLT) need to maintain an antiHBs titer of $500 \mathrm{IU} / \mathrm{L}$ with concomitant use of lamivudine (LAM). However, long-term administration of HBIg is associated with several unresolved issues, including limited availability and extremely high cost, so several arrangements have been reported [8, 10-12]. Low-dose HBIg resulting in a median $\mathrm{HBs} A b$ titer of $68 \mathrm{IU} / \mathrm{L}$ and combination with high-dose LAM at $300 \mathrm{mg} /$ day has prevented HBsAg recurrence in $96 \%$ of cases [12]. Low-dose HBIg administration only when $\mathrm{HBsAb}$ titers dropped to $<70 \mathrm{IU} /$ L combined with LAM at $100 \mathrm{mg}$ /day has completely prevented HBsAg recurrence [11]. We have already reported that high-dose HBIg in the early period followed by lowdose HBIg with nucleos(t)ide analogues offers reliable, cost-effective control of hepatitis B recurrence [13].

Naïve hepatocytes could be infected by virus release from extrahepatic sites, including the serum. Even after 10 years of successful clinical viral control post-OLT, more than half of patients were reportedly reinfected with the virus as confirmed by HBV covalently closed circular (ccc) DNA positivity of liver biopsy specimens [14]. The risk of clinical HBV recurrence reportedly correlates with high serum viral load pre-OLT. However, rates of reinfection to engrafted hepatocytes and correlations between reinfection and clinical recurrence rates are not well documented. Few reports have confirmed the existence of postOLT HBV cccDNA, the intrahepatic HBV replication intermediate in infected hepatocytes.

A new assay has recently been developed for detecting hepatitis B core-related antigen (HBcrAg), consisting of $\mathrm{HBV}$ core antigen ( $\mathrm{HBcAg}$ ), $\mathrm{HBV}$ e antigen ( $\mathrm{HBeAg}$ ), and a 22-kDa precore protein (p22cr) coded by the precore/core gene $[15,16]$. HBcrAg has been reported as a serum marker that could estimate intrahepatic HBV cccDNA [17].

To investigate intrahepatic HBV reinfection status with the clinically successful therapy of short-term high-dose HBIg followed by long-term low-dose HBIg and nucleos(t)ide analogues therapy, we quantified intrahepatic HBV cccDNA and serum HBcrAg.

\section{Materials and methods}

Patients and samples

From October 1996 to February 2009, living donor liver transplantation (LDLT) was performed in 206 patients at Okayama University Hospital. Of these, 34 cases showed HBV-related liver cirrhosis. The overall actual survival rate of patients is shown in Fig. 1. Five-year survival rates were $85 \%$ and $84 \%$ for all patients and for patients with HBVrelated liver cirrhosis, respectively.

Our HBV prophylaxis protocol was as follows. We administered $\mathrm{HBIg}$ at $200 \mathrm{IU} / \mathrm{kg}$ intraoperatively. Former patients received the same dose for an additional 1 week postoperatively. HBIg was thereafter administered once only at 2,000 IU for $\mathrm{HBsAb}$ titers $<100 \mathrm{IU} / \mathrm{L}$. After 6 months, HBIg was administered only for HBsAb titers $<10$ IU/L. We measured HBsAg and HBsAb and/or HBVDNA every month for 6 months after LDLT and every 2-3 months thereafter. Two of the $34 \mathrm{HBV}$-related LDLT patients dropped out from our HBV prophylaxis protocol and were thus excluded from this study. The general characteristics of patients included in this study are summarized in Table 1. Patients were treated using a standard immunosuppressive regimen (tacrolimus or cyclosporine A and azathioprine or mycophenolate mofetil with steroids) and nucleos(t)ide analogues were administered to all patients. Nucleos $(\mathrm{t})$ ide analogues were started a minimum of 1 month preoperatively, as possible.

Serum samples and explanted liver and biopsy specimens were obtained from these patients at our hospital after obtaining informed consent. Explanted liver samples were obtained from 12 patients. We performed protocol biopsies at 1,3 , and 5 years after OLT. We explained the necessity of routine liver biopsy to all patients after LDLT, but 19 of the 32 patients did not agree and biopsy specimens were thus obtained from 13 patients. All serum samples were stored at $-80^{\circ} \mathrm{C}$ until analysis.

All study protocols were approved by the Ethics Committee at the Okayama University Hospital.

\section{Routine laboratory tests}

$\mathrm{HBsAg}, \mathrm{HBeAg}, \mathrm{HBsAb}$, and $\mathrm{HBeAb}$ were routinely measured using a commercially available chemiluminescent

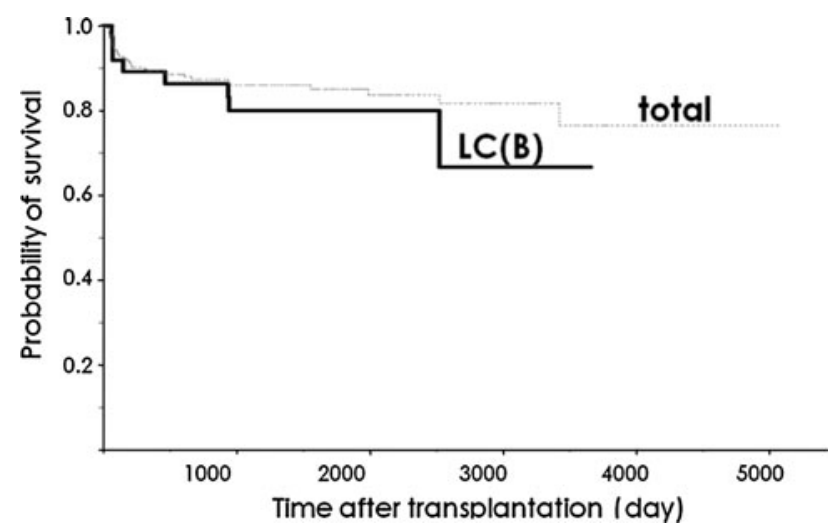

Fig. 1 Survival curve. Post-OLT survival of patients with LC(B) was comparable to that of all patients. $\mathrm{LC}(\mathrm{B})$, type $\mathrm{B}$ liver cirrhosis 
Table 1 General characteristics of patients

\begin{tabular}{|c|c|c|}
\hline & Total & With explanted liver \\
\hline Patients & 32 & 12 \\
\hline Age $(\text { years })^{\mathrm{a}}$ & $51.5(26-63)$ & $52.5(44-63)$ \\
\hline Gender (male/female) & $29 / 3$ & $11 / 1$ \\
\hline Hepatitis virus, $\mathrm{HBV} / \mathrm{HBV}+\mathrm{HCV}$ & $30 / 2$ & $12 / 0$ \\
\hline Hepatic malignancy & 17 & 7 \\
\hline Donor anti-HBc status (positive/negative) & $13 / 19$ & $7 / 5$ \\
\hline \multicolumn{3}{|l|}{ Antiviral prescription pre-OLT } \\
\hline$n(\%)$ & $32(100)$ & $12(100)$ \\
\hline Duration (days) $^{\mathrm{a}}$ & $56(3-1,793)$ & $163.5(5-1,793)$ \\
\hline Lamivudine/lamivudine + adefovir/entecavir & $25 / 4 / 3$ & $8 / 2 / 2$ \\
\hline \multicolumn{3}{|l|}{ Characteristics at OLT } \\
\hline Serum HBV-DNA: detectable (\%) & 57 & 42 \\
\hline HBV-DNA level in detectable cases $\left(\log _{10} \text { copies } / \mathrm{mL}\right)^{\mathrm{a}}$ & $4.1(2.7-5.5)$ & $3.5(2.7-4.8)$ \\
\hline HBV genotype (C/not analyzed) & $20 / 12$ & $9 / 3$ \\
\hline HBeAg status (positive/negative) & $15 / 17$ & $4 / 8$ \\
\hline Immunosuppressant (tacrolimus/cyclosporine A) & $26 / 6$ & $11 / 1$ \\
\hline Duration of post-OLT follow-up (months) ${ }^{a}$ & $38(2-103)$ & $35(4-53)$ \\
\hline Recurrence (presence of serum HBsAg/hepatitis) & $0 / 0$ & $0 / 0$ \\
\hline
\end{tabular}

Post-OLT reinfection with HBV was defined as positivity for any of the following HBV markers: serum HBsAg, serum HBcrAg, serum HBVDNA, or intrahepatic HBV cccDNA

$D N A$ deoxyribonucleic acid, anti-HBc antibody to hepatitis B core antigen, $H B e A g$ hepatitis B e antigen, $H B s A g$ hepatitis B surface antigen, $H B V$ hepatitis B virus, $H C V$ hepatitis $\mathrm{C}$ virus, $O L T$ orthotopic liver transplantation

a Median (range)

enzyme immunoassay (CLEIA) system (Lumipulse System; Fujirebio, Tokyo, Japan).

\section{Serum HBcrAg assay}

Serum HBcrAg was retrospectively measured using a CLEIA HBcrAg assay kit (Fujirebio) with a fully automated analyzer system (Lumipulse System, Fujirebio). Briefly, serum was mixed with pretreatment solution containing sodium dodecylsulfate and Tween 60 , then incubated at $60^{\circ} \mathrm{C}$ for $30 \mathrm{~min}$. This pretreated serum was added to a well coated with monoclonal antibodies against denatured $\mathrm{HBc}$ and $\mathrm{HBe}$ antigens. After $10 \mathrm{~min}$ of incubation at $37^{\circ} \mathrm{C}$, wells were washed with buffer. Alkaline phosphataselabeled monoclonal antibodies against denatured $\mathrm{HBc}$ and $\mathrm{HBe}$ antigens were added to the well and incubated for $10 \mathrm{~min}$ at $37^{\circ} \mathrm{C}$. After washing, substrate solution was added and incubated for $5 \mathrm{~min}$ at $37^{\circ} \mathrm{C}$. Relative chemiluminescence intensity was measured at $477 \mathrm{~nm}$, and the HBcrAg concentration was determined [15].

\section{Serum HBV-DNA assay}

HBV-DNA level was measured using a transcriptionmediated amplification assay (TMA) (SRL, Tokyo, Japan), polymerase chain reaction (PCR) assay (Amplicor $\mathrm{HBV}$ Monitor assay; Roche Diagnostics, Tokyo, Japan) or realtime PCR assay (COBAS TaqMan HBV Test; Roche Diagnostics).

Measurement of intrahepatic HBV cccDNA and $\beta$-globin levels

Liver biopsy specimens were immediately divided into two aliquots. One was formalin fixed for histological diagnosis, and the other was frozen within one minute for DNA analysis. The aliquot for DNA analysis was stored at $-80^{\circ} \mathrm{C}$ until DNA extraction. HBV-DNA was extracted using a QIAamp DNA Mini Kit (Qiagen, Tokyo, Japan).

Intrahepatic cccDNA was retrospectively measured using real-time PCR methods, as described previously [17]. To detect cccDNA, two oligonucleotide primers of HBVccc F1547 (5'-cccotctgtgccttctc- $3^{\prime}$, nucleotides 1,547-1,564) and HBVcccR1863 (5'-gcacagcttggaggcttgaa- $3^{\prime}$, nucleotides $1,882-1,863)$, and the probe cccP2 $\left(5^{\prime}\right.$-VIC-accaatttatgcct acag-MGB-3', nucleotides 1,672-1,655) were administered, as described previously, with minor modification [17]. Selective primers for cccDNA amplification were targeted across the single-stranded gap region of relaxed circular (RC) HBV-DNA. To enhance the specificity of cccDNA detection, 
plasmid-safe DNase (Epicentre, Madison, WI, USA) was used to degrade RC and single-stranded forms of viral DNA prior to PCR. Plasmid-safe DNase treatment of virion-associated DNA prevented amplification, confirming that this DNase degraded RC forms of HBV-DNA [18].

Real-time PCR was performed in a Light-Cycler (Roche Diagnostics). Cycling conditions of the assay were as follows: an initial $10 \mathrm{~min}$ at $95^{\circ} \mathrm{C}$ for DNA polymerase activation, followed by 45 cycles of $15 \mathrm{~s}$ denaturation at $95^{\circ} \mathrm{C}$, and $90 \mathrm{~s}$ annealing and extension at $60^{\circ} \mathrm{C}$. A $20-\mu \mathrm{L}$ reaction volume containing $5 \mu \mathrm{L}$ of extracted nucleic acid, $0.12 \mu \mathrm{mol} / \mathrm{L}$ of forward and reverse primers, $0.10 \mu \mathrm{mol} / \mathrm{L}$ of probe and $10 \mu \mathrm{L}$ of LightCycler480 Probes Mater (Roche Diagnostics) was administered. Serial dilutions of a plasmid containing HBV-DNA extracted and cloned from the serum of a 36-year-old Japanese woman (genotype C) served as quantification standards. HBV cccDNA values were normalized for cellular DNA content using a commercially available $\beta$-globin gene kit (Roche DNA Control Kit; Roche Diagnostics).

The lower limit of detection for the HBV cccDNA was $-4 \log _{10}$ copies/cell.

Immunohistochemical staining

Immunohistochemical staining was performed on sections of fixed liver tissues using a three-step horseradish peroxidase technique. The primary monoclonal antibodies employed were anti-HBsAg and anti-HBcAg (Dako, Tokyo, Japan).

\section{Statistical analysis}

Statistical comparisons were performed using JMP version 7.0.1 (SAS Institute, Cary, NC, USA). For nonparametric pair-wise comparisons, the Spearman rank correlation coefficient was used, and the Wilcoxon rank sum test was used for two-group comparisons. A value of $P<0.05$ was considered significant. All statistical tests were two-sided. We performed per protocol analysis.

\section{Results}

Clinical course of patients

The 32 patients investigated comprised of $15 \mathrm{HBeAg-}$ positive and $17 \mathrm{HBeAg-negative} \mathrm{patients} \mathrm{(Table} \mathrm{1).} \mathrm{Mean}$ duration of follow-up was $1,150.5 \pm 869.8$ days (range 61-3,090 days) after OLT. No patient showed recurrence of serum HBsAg or serum HBV-DNA with real-time PCR assay (Fig. 2). After 6 months postoperatively, HBIg was used only 0.24 times/month, representing once every 4 months.
Explanted liver samples were obtained from 12 of the 32 patients, including $4 \mathrm{HBeAg}$-positive and $8 \mathrm{HBeAg-nega-}$ tive patients (Table 1). Serum HBV-DNA was detectable in five patients $(42 \%)$, with a median HBV-DNA level of $3.5 \log _{10}$ copies/mL. Seven patients showed malignant hepatic tumor. All 12 patients received pre-OLT antiviral therapy for a median duration of 163.5 days. Mean followup was $1,051 \pm 416$ days (range 115-1,576 days) after OLT.

HBV viral status at the time of OLT

Serum HBV-DNA levels and serum HBcrAg at the time of OLT were positively correlated $(r=0.461, P<0.05)$ (Fig. 3a). HBV cccDNA was detected in 11 patients (83\%), with median HBV cccDNA levels of $-0.77 \log _{10}$ copies/cell. A significant positive correlation was observed between explanted liver cccDNA and serum HBV-DNA ( $r=0.760, \quad P<0.005$ ) (Fig. 3b). Although 6 of 12 patients from whom explanted livers were obtained were serum HBV-DNA negative at OLT, 5 of those 6 patients were positive for serum $\mathrm{HBcrAg}$ and intrahepatic $\mathrm{HBV}$ cccDNA.

Time course of serum HBcrAg, intrahepatic HBV cccDNA and intrahepatic $\mathrm{HBsAg} / \mathrm{HBcAg}$

A total of 13 patients with 14 biopsies collected between 11 and 74 months post-OLT were studied (Table 2). After OLT, median serum HBcrAg decreased from 4.78 $\log _{10} \mathrm{IU} / \mathrm{mL}$ to undetectable $(P<0.0001)$ (Fig. 4a). Seven biopsy specimens showed no detectable HBV cccDNA. The median concentration of $\mathrm{HBV}$ cccDNA was -3.19 $\log _{10}$ copies/cell. Median cccDNA decreased from -0.77 to $-3.19 \log _{10}$ copies/cell. This equates to a $-0.77 \log _{10}$

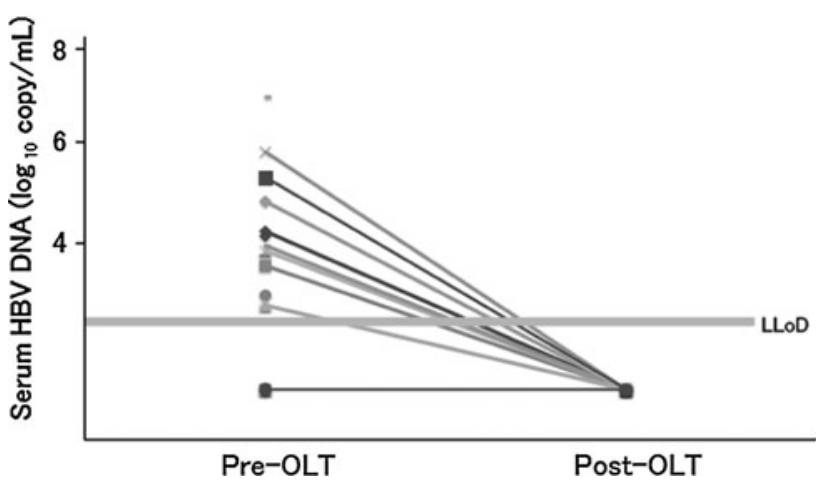

Fig. 2 Serum HBV-DNA titer pre- and post-OLT. No patients showed recurrence of serum HBV-DNA with real-time PCR assay. $L L o D$ lower limit of detection 
Fig. 3 Correlations between HBV-related markers at the time of OLT. Significant correlations were apparent between: a serum HBcrAg and serum HBV-DNA $(r=0.461$, $P<0.05)$; and $\mathbf{b}$ intrahepatic cccDNA and serum HBV-DNA $(r=0.625, P<0.05)$
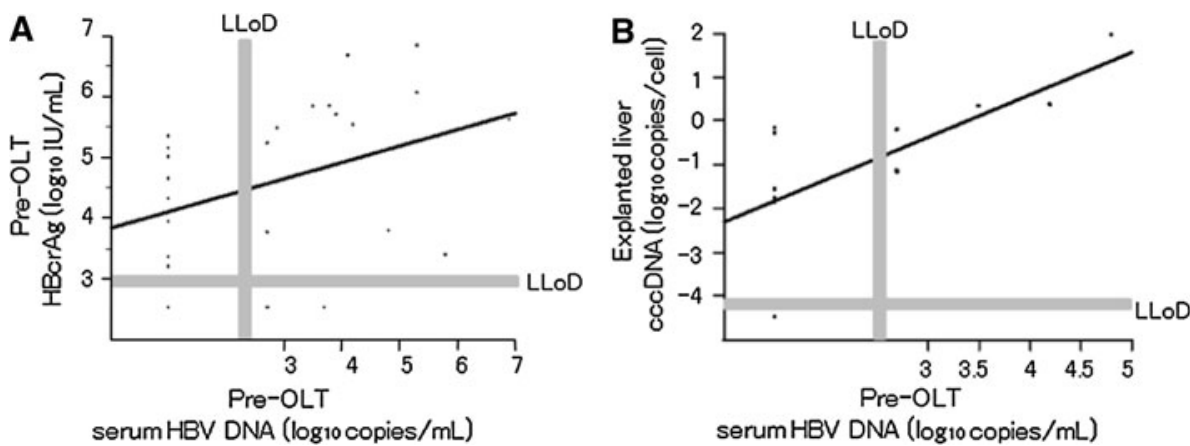

decrease $(P<0.005)$ in cccDNA levels achieved after OLT (Fig. 4b).

Serum HBcrAg was detectable in $48 \%$ of patients (10/ 21) after 1,252 days post-OLT. Intrahepatic HBV cccDNA was positive in $57 \%$ of patients (8/14) after 670.5 days post-OLT (Fig. 4c).

$\mathrm{HBsAg} / \mathrm{HBcAg}$ immunohistochemical staining was studied in the 14 biopsied liver specimens. All samples were negative for $\mathrm{HBsAg} / \mathrm{HBcAg}$ immunohistochemical staining.

Correlation between pre-OLT serum HBV-DNA and post-OLT HBcrAg, intrahepatic HBV cccDNA

No significant correlation was identified between pre-OLT serum HBV-DNA and post-OLT serum HBcrAg (Fig. 5a). A linear correlation was apparent between serum levels of HBV-DNA at the time of OLT and post-OLT cccDNA ( $r=0.534, P<0.05$ ) (Fig. 5b). All eight patients $(100 \%)$ with serum HBV-DNA $<3 \log _{10}$ copies/mL at the time of OLT showed lower than $-2 \log _{10}$ copies/cell of HBV cccDNA at post-OLT, while patients with pre-OLT serum HBV-DNA $>3 \log _{10}$ copies/mL showed a significantly higher rate of post-OLT cccDNA higher than $-2 \log _{10}$ copies/cell $(P<0.003)$ (Fig. 5c).

Correlation between pre-OLT HBcrAg and post-OLT HBcrAg and intrahepatic HBV cccDNA

No significant correlation was found between pre-OLT HBcrAg and post-OLT serum HBcrAg (Fig. 6a). However, a linear correlation was observed between $\mathrm{HBcrAg}$ at the time of OLT and post-OLT cccDNA $(r=0.634, P<0.05)$ (Fig. 6b). All six patients $(100 \%)$ with $\mathrm{HBcrAg}>4 \log _{10}$ $\mathrm{IU} / \mathrm{mL}$ at the time of OLT showed detectable HBV cccDNA post-OLT, while patients with pre-OLT HBcrAg $<4 \log _{10} \mathrm{IU} / \mathrm{mL}$ showed a significantly lower rate $(14 \%)$ of detectable cccDNA post-OLT $(P<0.001)$ (Fig. 6c).

Age at OLT, gender, HCC at OLT, HBeAg status at OLT, donor anti-HBc status, follow-up duration, immunosuppressive agents, antiviral agents, and duration of antiviral agent administration showed no effect on intrahepatic levels of cccDNA after OLT.

\section{Discussion}

This study found that even under clinically successful HBV control post-OLT, serum $\mathrm{HBcrAg}$ and intrahepatic $\mathrm{HBV}$ cccDNA were detectable in $48 \%$ and $57 \%$ of patients, respectively. Pre-OLT high serum HBV-DNA titer could predict post-OLT cccDNA level.

In 1991, Müller et al. [19] reported the first use of longterm HBIg immunoprophylaxis, reducing recurrence rate to $25 \%$ for 6 months and $18 \%$ for 12 months. In 1993 , Samuel et al. [20] reported a multicenter study in which the 3 -year-risk of $\mathrm{HBV}$ recurrence was $75 \pm 6 \%$ in patients without $\mathrm{HBIg}, 74 \pm 5 \%$ with short-term (2-month) $\mathrm{HBIg}$ and $36 \pm 4 \%$ with long-term (>6-month) HBIg treatment. Patients who were positive for HBeAg or HBV-DNA displayed the greatest risk of recurrence $(83 \%)$ and patients with acute fulminant liver failure showed the lowest risk (16\%).

In 1996, Grellier et al. [21] reported a trial of LAM as a prophylactic treatment achieving only $18 \%$ recurrence of HBV by 6 months after OLT. However, the long-term recurrence rate at 3 years after OLT had progressed to $41 \%$, indicating that LAM monotherapy is not recommendable for post-transplantation prophylaxis.

Although monotherapy with HBIg or LAM results in a high rate of recurrence, a combination of these agents has been administered with reasonable success. In 1998, Markowitz et al. [22] reported no recurrences after 1 year with combination therapy. Since HBIg is very expensive, several reports have described modified combination therapies. We have previously shown that long-term LAM with short-term high-dose HBIg followed by low-dose HBIg sufficient to maintain $\mathrm{HBsAb}$ titer $<10 \mathrm{IU} / \mathrm{L}$ is costeffective and powerful enough to control HBV recurrence after LDLT. With this cost-saving method, no clinical evidence of $\mathrm{HBV}$ recurrence has been seen. Intrahepatic HBV cccDNA has been shown to be positive in $57 \%$ of 


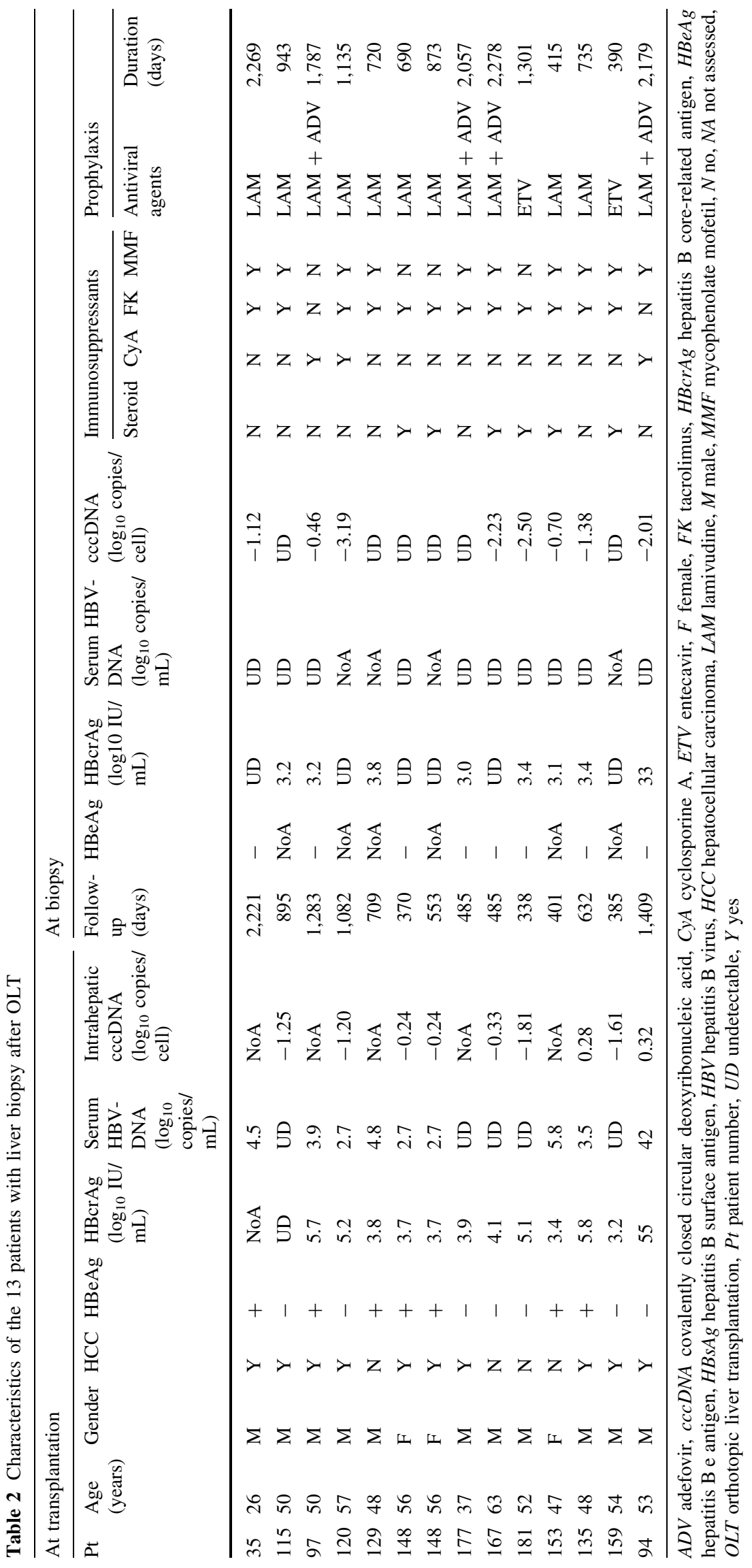


Fig. 4 Time course of serum HBcrAg (a), and intrahepatic HBV cccDNA (b). Significant decreases were observed (a $P<0.0001$, b $P<0.005$ ). Serum HBcrAg was detectable in $48 \%$ of patients after 1,252 days post-OLT. Intrahepatic HBV cccDNA was positive in $57 \%$ of patients at 670.5 days post-OLT (c)
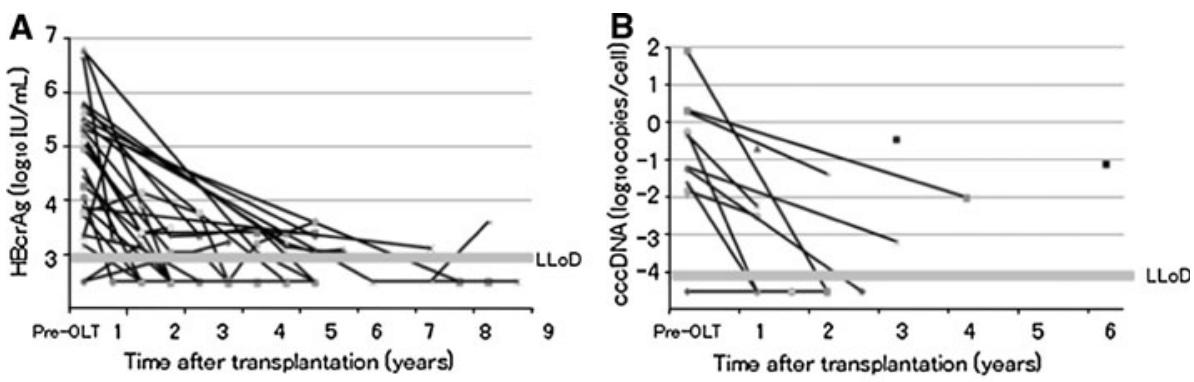

\begin{tabular}{|c|c|c|}
\hline & Positvity (\%) & Median time after OLT (days) \\
\hline HBcrAg & 48 & 1252 \\
\hline cccDNA & 57 & 670.5 \\
\hline
\end{tabular}

Fig. 5 Correlation between pre-OLT serum HBV-DNA and post-OLT HBcrAg (a), and preOLT serum HBV-DNA and post-OLT HBV cccDNA (b). A linear correlation was observed in $\mathbf{b}(r=0.534, P<0.05)$, but not in a. All eight patients (100\%) with serum HBV-DNA $<3 \log _{10}$ copies/mL at the time of OLT showed post-OLT cccDNA $<2 \log _{10}$ copies/cell, significantly higher than the rate of $33 \%$ found in patients with higher HBV-DNA levels (two of six patients) $(P<0.003)(\mathbf{c})$
Fig. 6 Correlation between pre-OLT HBcrAg and post-OLT HBcrAg (a), and pre-OLT HBcrAg and post-OLT HBV cccDNA (b). A linear correlation was observed in b $(r=0.634, P<0.05)$, but not in a. All six patients $(100 \%)$ with $\mathrm{HBcrAg}>4 \log _{10} \mathrm{IU} / \mathrm{mL}$ at the time of OLT showed HBV cccDNA detectable at post-OLT, while patients with pre-OLT HBcrAg $<4$ $\log _{10} \mathrm{IU} / \mathrm{mL}$ showed a significantly higher rate of undetectable cccDNA post-OLT $(P<0.001)(\mathbf{c})$
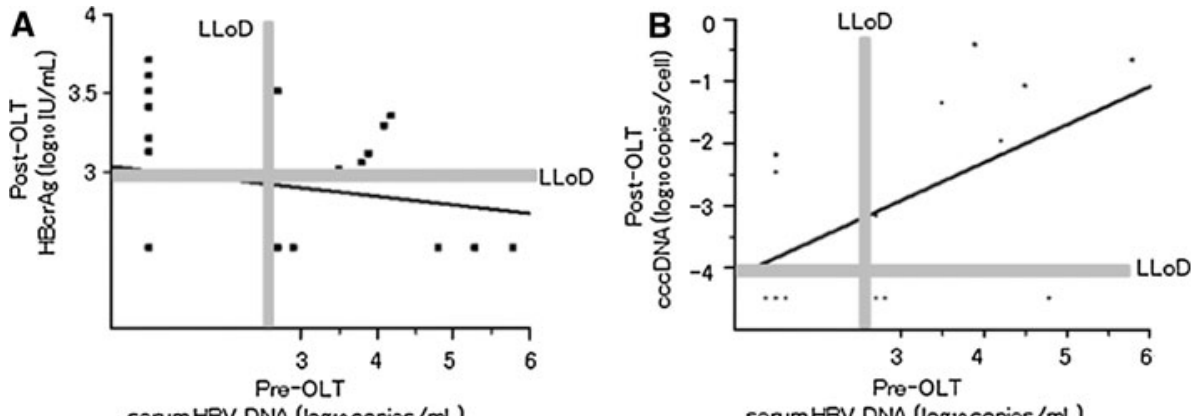

serum HBV DNA (log 10 copies $/ \mathrm{mL}$ ) serumHBV DNA (log10copies/mL)

\begin{tabular}{|c|c|c|c|}
\hline \multicolumn{2}{|c|}{} & \multicolumn{2}{c|}{$\begin{array}{c}\text { Post-OLT intrahepatic } \\
\text { cccDNA(log copies/cell) }\end{array}$} \\
\cline { 3 - 4 } & $\geq-2$ & $<-2$ \\
\hline $\begin{array}{c}\text { Pre-OLT serum } \\
\text { HBV-DNA } \\
(\text { Iog copies/mL) }\end{array}$ & $\geq 3$ & 4 & 2 \\
\cline { 2 - 4 } & $<3$ & 0 & 8 \\
\hline
\end{tabular}
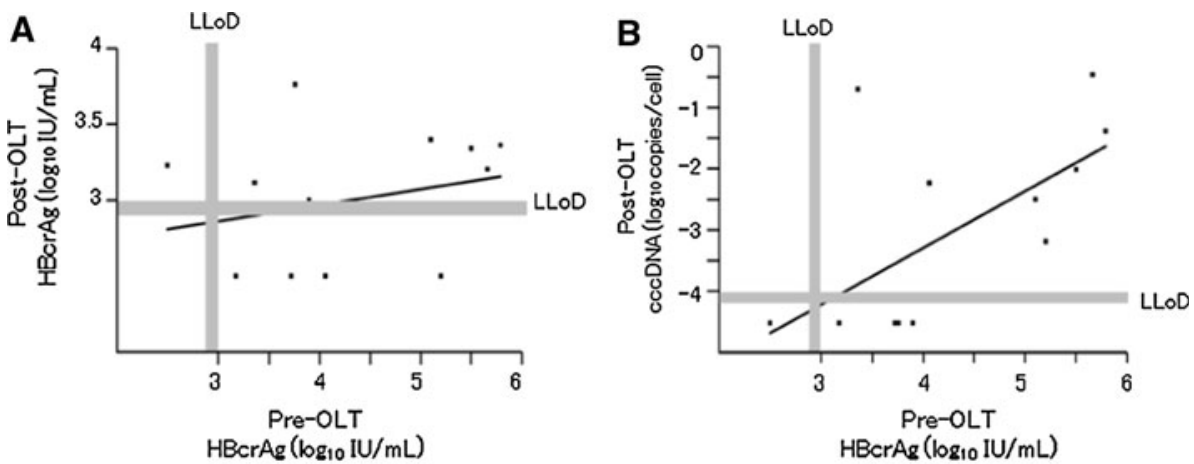

\begin{tabular}{|c|c|c|c|}
\hline \multicolumn{2}{|c|}{} & \multicolumn{2}{c|}{$\begin{array}{r}\text { Post-OLT intrahepatic } \\
\text { cccDNA(logio copies/cell) }\end{array}$} \\
\cline { 3 - 4 } & detectable & undetectable \\
\hline \multirow{2}{|c|}{} & $\geq 4$ & 6 & 0 \\
\hline $\begin{array}{c}\text { Pre-OLT } \\
\text { HBcrAg } \\
(\text { logidU/mL) }\end{array}$ & $<4$ & 1 & 6 \\
\cline { 2 - 4 } & & 1 & \\
\hline
\end{tabular}


patients. This would be comparable to the findings from previous reports showing positive results for HBV cccDNA post-OLT [23].

Intrahepatic HBV cccDNA could be detected in almost all patients with HBV-related cirrhosis pre-OLT, although all patients had received antiviral therapy pre-OLT and half of the patients had undetectable serum HBV-DNA. Recent studies have also shown that suppression of HBV-DNA in serum does not indicate clearance of the virus from hepatocytes [24], and the long half-life of cccDNA in reinfected hepatocytes is responsible for viral recurrence following OLT [19, 25-29]. Several reports have noted that high preOLT serum HBV-DNA levels would predict HBV recurrence post-OLT [30, 31].

Our data indicate that higher pre-OLT serum HBVDNA levels and HBcrAg levels correlate with post-OLT cccDNA levels. Even with our successful protocol, patients with high pre-OLT serum HBV-DNA levels and HBcrAg levels, particularly $>3 \log _{10}$ copies/mL and $>4 \log _{10}$ IU/ $\mathrm{mL}$, respectively, should be followed with care for $\mathrm{HBV}$ recurrence.

HBV is an enveloped DNA virus containing an RC DNA genome, which is converted into a cccDNA in the nucleus of infected cells. The cccDNA episome is the transcriptional template for HBV messenger RNA transcripts that encode viral structural and non-structural proteins and the $3.5-\mathrm{kb}$ pregenomic (pg) RNA template for reverse transcription and synthesis of the viral genome. The pg RNA serves as the template for reverse transcription to generate viral DNA. Nucleos $(\mathrm{t})$ ide analogues inhibit the reverse transcription of pg RNA, and can thus rapidly decrease serum levels of HBV-DNA, but cannot eliminate the cccDNA reservoir. The cccDNA is thus recognized as a putative marker for real HBV-DNA replication ability that might suggest the suitable time to withdraw nucleos(t)ide analogues. HBcrAg, representing a complex of $\mathrm{HBeAg}$, $\mathrm{HBcAg}$, and $\mathrm{p} 22 \mathrm{cr}$, has been shown to correlate with cccDNA [17]. HBcrAg would thus represent a good noninvasive marker to recognize intrahepatic $\mathrm{HBV}$ replication status. The present data show positive results for $\mathrm{HBcrAg}$ as frequently as for intrahepatic HBV cccDNA (Fig. 4). Although evaluation for low titers of $\mathrm{HBcrAg}$ would be difficult (Fig. 5a), positive HBcrAg offers a good marker to confirm HBV reinfection after OLT. Even when serum HBV-DNA is undetectable, patients at higher risk of HBV recurrence can be differentiated from those at lower risk of HBV recurrence who can be withdrawn from HBIg or nucleos $(\mathrm{t})$ ide analogues by high $\mathrm{HBcrAg}$ positivities.

In conclusion, long-term nucleos(t)ide analogues with short-term high-dose HBIg followed by low-dose HBIg supplementation only when the HBsAb titer falls below $10 \mathrm{IU} / \mathrm{L}$ is sufficient to suppress intrahepatic HBV-DNA replication and control HBV recurrence after OLT.
However, almost half of the patients were positive for intrahepatic HBV cccDNA and serum HBcrAg, even though titers were low. Patients with high pre-OLT serum HBV-DNA levels, high pre-OLT HBcrAg levels, and positive post-OLT results for HBcrAg should be carefully followed to identify patients who might show HBV recurrence.

Open Access This article is distributed under the terms of the Creative Commons Attribution Noncommercial License which permits any noncommercial use, distribution, and reproduction in any medium, provided the original author(s) and source are credited.

\section{References}

1. Todo S, Demetris AJ, Van Thiel D, Teperman L, Fung JJ, Starzl TE. Orthotopic liver transplantation for patients with hepatitis B virus-related liver disease. Hepatology 1991;13:619-626

2. Davies SE, Portmann BC, O'Grady JG, Aldis PM, Chaggar K, Alexander GJ, Williams R. Hepatic histological findings after transplantation for chronic hepatitis B virus infection, including a unique pattern of fibrosing cholestatic hepatitis. Hepatology 1991;13:150-157

3. O'Grady JG, Smith HM, Davies SE, Daniels HM, Donaldson PT, Tan KC, Portmann B, Alexander GJ, Williams R. Hepatitis B virus reinfection after orthotopic liver transplantation. Serological and clinical implications. J Hepatol 1992;14:104-111

4. Fontana RJ, Hann HW, Wright T, Everson G, Baker A, Schiff ER, Riely C, Anschuetz G, Riker-Hopkins M, Brown N, Lamivudine Compassionate Use Study Group. A multicenter study of lamivudine treatment in 33 patients with hepatitis B after liver transplantation. Liver Transplant 2001;7(6):504-510

5. Bartholomew MM, Jansen RW, Jeffers LJ, Reddy KR, Johnson LC, Bunzendahl H, Condreay LD, Tzakis AG, Schiff ER, Brown NA. Hepatitis-B virus resistance to lamivudine given for recurrent infection after orthotopic liver transplantation. Lancet 1997;349:20-22

6. Papatheodoridis GV, Sevastianos V, Burroughs AK. Prevention of and treatment for hepatitis B virus infection after liver transplantation in the nucleoside analogues era. Am J Transplant 2003;3:250-258

7. Yoshida H, Kato T, Levi DM, Regev A, Madariaga JR, Nishida S, Martinez EJ, Schiff ER, Omata M, Tzakis AG. Lamivudine monoprophylaxis for liver transplant recipients with non-replicating hepatitis B virus infection. Clin Transplant 2007;21:166-171

8. Ferretti G, Merli M, Ginanni Corradini S, Callejon V, Tanzilli P, Masini A, Ferretti S, Iappelli M, Rossi M, Rivanera D, Lilli D, Mancini C, Attili A, Berloco P. Low-dose intramuscular hepatitis $\mathrm{B}$ immune globulin and lamivudine for long-term prophylaxis of hepatitis B recurrence after liver transplantation. Transplant Proc 2004;36:535-538

9. Roche B, Samuel D. Evolving strategies to prevent HBV recurrence. Liver Transplant 2004;10(Suppl 2):S74-S85

10. Buti M, Mas A, Prieto M, Casafont F, González A, Miras M, Herrero JI, Jardí R, Cruz de Castro E, García-Rey C. A randomized study comparing lamivudine monotherapy after a short course of hepatitis B immune globulin (HBIg) and lamivudine with long-term lamivudine plus HBIg in the prevention of hepatitis B virus recurrence after liver transplantation. J Hepatol 2003;38:811-817

11. Di Paolo D, Tisone G, Piccolo P, Lenci I, Zazza S, Angelico M. Low dose hepatitis B immunoglobulin given 'on demand' in 
combination with lamivudine: a highly cost-effective approach to prevent recurrent hepatitis B virus infection in the long-term follow-up after liver transplantation. Transplantation 2004;77: 1203-1208

12. Karasu Z, Ozacar T, Akyildiz M, Demirbas T, Arikan C, Kobat A, Akarca U, Ersoz G, Gunsar F, Batur Y, Kilic M, Tokat Y. Low-dose hepatitis B immune globulin and higher-dose lamivudine combination to prevent hepatitis B virus recurrence after liver transplantation. Antivir Ther 2004;9:921-927

13. Takaki A, Yagi T, Iwasaki Y, Sadamori H, Matsukawa H, Matsuda H, Shinoura S, Umeda Y, Miyake Y, Terada R, Kobashi H, Sakaguchi K, Tanaka N, Shiratori Y. Short-term high-dose followed by long-term low-dose hepatitis B immunoglobulin and lamivudine therapy prevented recurrent hepatitis B after liver transplantation. Transplantation 2007;83:231-233

14. Roche B, Feray C, Gigou M, Roque-Afonso AM, Arulnaden JL, Delvart V, Dussaix E, Guettier C, Bismuth H, Samuel D. HBV DNA persistence 10 years after liver transplantation despite successful anti-HBS passive immunoprophylaxis. Hepatology 2003;38(1):86-95

15. Kimura T, Rokuhara A, Sakamoto Y, Yagi S, Tanaka E, Kiyosawa K, Maki N. Sensitive enzyme immunoassay for hepatitis $\mathrm{B}$ virus core-related antigens and their correlation to virus load. J Clin Microbiol 2002;40:439-445

16. Kimura T, Ohno N, Terada N, Rokuhara A, Matsumoto A, Yagi S, Tanaka E, Kiyosawa K, Ohno S, Maki N. Hepatitis B virus DNA-negative Dane particles lack core protein but contain a 22-kDa precore protein without C-terminal arginine-rich domain. J Biol Chem 2005;280:21713-21719

17. Suzuki F, Miyakoshi H, Kobayashi M, Kumada H. Correlation between serum hepatitis B virus core-related antigen and intrahepatic covalently closed circular DNA in chronic hepatitis B patients. J Med Virol 2009;81:27-33

18. Werle-Lapostolle B, Bowden S, Locarnini S, Wursthorn K, Petersen J, Lau G, Trepo C, Marcellin P, Goodman Z, Delaney WE 4th, Xiong S, Brosgart CL, Chen SS, Gibbs CS, Zoulim F. Persistence of cccDNA during the natural history of chronic hepatitis $\mathrm{B}$ and decline during adefovir dipivoxil therapy. Gastroenterology 2004;126:1750-1758

19. Müller R, Gubernatis G, Farle M, Niehoff G, Klein H, Wittekind C, Tusch G, Lautz HU, Böker K, Stangel W. Liver transplantation in HBs antigen ( $\mathrm{HBsAg}$ ) carriers. Prevention of hepatitis B virus (HBV) recurrence by passive immunization. J Hepatol 1991;13:90-96

20. Samuel D, Muller R, Alexander G, Fassati L, Ducot B, Benhamou JP, Bismuth H. Liver transplantation in European patients with the hepatitis B surface antigen. N Engl J Med 1993;329: $1842-1847$
21. Grellier L, Mutimer D, Ahmed M, Brown D, Burroughs AK, Rolles K, McMaster P, Beranek P, Kennedy F, Kibbler H, McPhillips P, Elias E, Dusheiko G. Lamivudine prophylaxis against reinfection in liver transplantation for hepatitis B cirrhosis. Lancet 1996;348:1212-1215

22. Markowitz JS, Martin P, Conrad AJ, Markmann JF, Seu P, Yersiz H, Goss JA, Schmidt P, Pakrasi A, Artinian L, Murray NG, Imagawa DK, Holt C, Goldstein LI, Stribling R, Busuttil RW. Prophylaxis against hepatitis B recurrence following liver transplantation using combination lamivudine and hepatitis B immune globulin. Hepatology 1998;28:585-589

23. Hussain M, Soldevila-Pico C, Emre S, Luketic V, Lok AS, NIH HBV-OLT Study Group. Presence of intrahepatic (total and ccc) HBV DNA is not predictive of HBV recurrence after liver transplantation. Liver Transplant 2007;13(8):1137-1144

24. Wursthorn K, Lutgehetmann M, Dandri M, Volz T, Buggisch P, Zollner B, Longerich T, Schirmacher P, Metzler F, Zankel M, Fischer C, Currie G, Brosgart C, Petersen J. Peginterferon alpha-2b plus adefovir induce strong cccDNA decline and HBsAg reduction in patients with chronic hepatitis B. Hepatology 2006;44:675-684

25. Sung JJ, Wong ML, Bowden S, Liew CT, Hui AY, Wong VW, Leung NW, Locarnini S, Chan HL. Intrahepatic hepatitis B virus covalently closed circular DNA can be a predictor of sustained response to therapy. Gastroenterology 2005;128:1890-1897

26. Mommeja-Marin H, Mondou E, Blum MR, Rousseau F. Serum HBV DNA as a marker of efficacy during therapy for chronic HBV infection: analysis and review of the literature. Hepatology 2003;37:1309-1319

27. Moraleda G, Saputelli J, Aldrich CE, Averett D, Condreay L, Mason WS. Lack of effect of antiviral therapy in nondividing hepatocyte cultures on the closed circular DNA of woodchuck hepatitis virus. J Virol 1997;71:9392-9399

28. Le Guerhier F, Pichoud C, Guerret S, Chevallier M, Jamard C, Hantz O, Li XY, Chen SH, King I, Trépo C, Cheng YC, Zoulim F. Characterization of the antiviral effect of 2, 3-dideoxy-2, 3-didehydro-beta-L-5-fluorocytidine in the duck hepatitis B virus infection model. Antimicrob Agents Chemother 2000;44:111-122

29. Mason WS, Cullen J, Moraleda G, Saputelli J, Aldrich CE, Miller DS, Tennant B, Frick L, Averett D, Condreay LD, Jilbert AR. Lamivudine therapy of WHV-infected woodchucks. Virology 1998;245:18-32

30. Marzano A, Gaia S, Ghisetti V, Carenzi S, Premoli A, DebernardiVenon W, Alessandria C, Franchello A, Salizzoni M, Rizzetto M. Viral load at the time of liver transplantation and risk of hepatitis B virus recurrence. Liver Transplant 2005;11(4):402-409

31. Han YS, Lee SK, Joh JW, Kim SJ, Kwon CH, Park JW, Kim DJ, Park JB. Outcomes of hepatitis B virus recurrence after liver transplantation. Transplant Proc 2006;38(7):2123-2124 